\title{
ANALISIS PUTUSAN PENGADILAN NEGERI SURABAYA NOMOR: 3094/PID.B/2013 TENTANG ALAT BUKTI OLEH HAKIM DALAM PASAL 114 AYAT (2) JUNCTO PASAL 132 AYAT (1) UU RI NOMOR 35 TAHUN 2009 TENTANG NARKOTIKA
}

\section{Tobias Gula Aran}

Fakultas Hukum Universitas Brawijaya

Malang, Jawa Timur

Email: marko_aran@yahoo.com

\section{Abstract}

In this research examines two issues, namely the Surabaya District Court Decision No. 3094 / Pid.B / 2013 In accordance with Evidence presented at trial and Parameter Verification assessed Judges in Crime Article 114 paragraph (2) in conjunction with Article 132 ( 1) Act No. 35 of 2009 on Narcotics, based on a normative juridical research, using the approach of Legislation, Case approach, analytical approach, the purpose of this study was to analyze the state court decision Surabaya number: 3094/Pid.B/2013 appropriate evidence presented at the hearing, stated that in this ruling the judge has not given a sense of justice for law enforcement against criminal acts Narcotics correspond to the penalty set out in the Act, and to describe the parameters of proof is rated Judge in a criminal act of Article 114 paragraph (2) in conjunction with Article 132 paragraph (1) of Law No. 35 Year 2009 on Narcotics, as the basis of the assessment of evidence by the judge.

Keywords: Court Decision Analysis, Evidence, Narcotics.

\section{Pendahuluan}

Pembuktian dalam perkara pidana (hukum acara pidana) adalah bertujuan untuk mencari kebenaran materil, yaitu kebenaran sejati atau yang sesungguhnya. Hukum pidana dalam mencari kebenaran materil, maka peristiwanya harus terbukti (beyond reasonable doubt).

Masalah pembuktian adalah yang sangat penting dan utama, sebagaimana menurut Pasal 6 ayat (2) KUHAP, bahwa "Tidak seorang pun dapat dijatuhi pidana, kecuali apabila pengadilan, karena alat pembuktian yang sah menurut undang- 
undang, mendapat keyakinan bahwa seorang yang dianggap dapat bertanggung jawab, telah bersalah atas perbuatan yang didakwakan atas dirinya."

Bahwa dalam perkara pidana, ajaran hukum mengajarkan teori mencari dan menemukan kebenaran materiil (materielle waarheid). Kebenaran yang memastikan pelaku/terdakwa bersalah atau tidak ditentukan dalam persidangan dengan merekonstruksi kenyataan dalam fakta-fakta hukum yang memerlukan pembuktian yang disebut dengan alat bukti yang sah secara materil. Menurut KUHAP yang wajib membuktikan dakwaannya adalah Jaksa Penuntut Umum.

Oleh karena itu, hakim dalam memutus perkara tidak boleh berada dalam bayangan keraguan yang tidak dapat dijelaskan berdasarkan keraguan pembuktian, sehingga jika alat bukti yang diajukan jaksa penuntut umum merupakan alat bukti yang meragukan maka alat bukti tersebut adalah bukti yang tidak meyakinkan dan tidak mempunyai kekuatan pembuktian apapun (Tabloid Hukum terdepan di Jatim, 2013, 09).

Di dalam KUHAP bagian ke-empat mengenai pembuktian dan putusan dalam acara pemeriksaan biasa, antara lain: diatur mengenai sistem pembuktian, macam-macam alat bukti dan kekuatan pembuktian. Hal-hal yang menyangkut hukum pembuktian diatur sebagai berikut: sistem pembuktian diatur dalam pasal 183 KUHAP, macam-macam alat bukti diatur dalam pasal 184 KUHAP, dan kekuatan pembuktian diatur dalam pasal 189 KUHAP.

Suatu negara yang berdasarkan atas hukum (rechttaats), kekuasaan kehakiman merupakan badan yang sangat menentukan isi dan kekuatan kaidahkaidah hukum positif. Kekuasaan kehakiman diimplementasikan dalam tindakan pemeriksaan, penilaian dan penetapan nilai perilaku manusia tertentu serta menentukan nilai situasi konkret dan menyelesaikan masalah atau konflik yang ditimbulkan secara imparsial berdasarkan hukum sebagai pijakan objektif (Lili Rasjidi, at al., 2004, 93).

Dalam putusan hakim harus dipertimbangkan segala aspek yang bersifat yuridis, sosiologis, dan filosofis, sehingga keadilan yang ingin dicapai, diwujudkan, dan dipertanggungjawabkan dalam putusan hakim adalah keadilan yang berorientasi pada keadilan hukum (legal justice), keadilan masyarakat (social justice), dan keadilan moral (moral justice).( Lilik Mulyadi, 2006, 21). 
Dalam melaksanakan tugasnya, hakim dituntut untuk bekerja secara profesional, bersih, arif, dan bijaksana, serta mempunyai rasa kemanusiaan yang tinggi, dan juga menguasai dengan baik teori-teori ilmu hukum.

Penjatuhan pidana merupakan upaya mempertahankan hukum pidana materil. Namun demikian, dalam dimensi kemasyarakatan dan kenegaraan, hukum merupakan tatanan kehidupan nasional, baik di bidang politik, ekonomi, sosial budaya, dan pertahanan keamanan. Dalam hal ini penjatuhan pidana merupakan salah satu upaya agar tercipta suatu ketertiban, keamanan, keadilan, serta kepastian hukum. Sehingga yang bersangkutan dapat menyadari kesalahannya, memperbaiki diri, dan tidak mengulangi tindak pidana (Bambang Waluyo, 2004, 35).

Penjatuhan pidana dan pemidanaan dapat dikatakan cermin peradilan pidana di negara kita. Apabila proses peradilan yang misalnya berakhir dengan penjatuhan pidana sesuai asas peradilan, niscaya peradilan negara kita dinilai baik. Apabila sebaliknya, tentu saja dinilai sebagai adanya kemerosotan kewibawaan hukum.

Penjatuhan putusan pidana dikatakan sebagai suatu proses, selain terikat pada sistem dan aturan juga melibatkan pihak-pihak tertentu. Pihak-pihak yang dimaksud adalah tersangka, terdakwa, penyidik, jaksa penuntut umum, hakim, dan penasihat hukum.

Terkait Undang-Undang Nomor 35 Tahun 2009 tentang Narkotika, sebagaimana yang diamanatkan dalam konsideran Undang-Undang Narkotika, bahwa ketersediaan narkotika jenis tertentu yang sangat dibutuhkan sebagai obat dimaksudkan untuk meningkatkan derajat kesehatan masyarakat, namun di sisi lain mengingat dampak yang dapat ditimbulkan dan tingkat bahaya yang ada apabila digunakan tanpa pengawasan dokter secara tepat dan ketat maka harus dilakukan tindakan pencegahan dan pemberantasan terhadap bahaya penyalahgunaan dan peredaran gelap narkotika (Kusno Adi, 2009, 18).

\section{Rumusan masalah}

Berdasarkan latar belakang di atas, permasalahan yang dirumuskan dalam penelitian ini adalah untuk mengetahui apakah putusan Pengadilan Negeri Surabaya Nomor: 3094/Pid.B/2013 sesuai dengan alat bukti yang diajukan di persidangan, dan bagaimana parameter pembuktian yang dinilai Hakim dalam 
tindak pidana pasal 114 ayat (2) juncto asal 132 ayat (1) UU RI Nomor 35 tahun 2009 tentang Narkotika.

\section{Metode Penelitian}

Jenis penelitian ini merupakan penelitian hukum normatif, yaitu penelitian yang mengkaji putusan pengadilan negeri Surabaya Nomor: 3094/Pid.B/2013 dalam perkara pidana khusus Narkotika. Adapun yang dikaji dalam penelitian ini adalah Undang-Undang Nomor 35 Tahun 2009 tentang Narkotika, UndangUndang Nomor 48 Tahun 2009 tentang Kekuasaan Kehakiman, KUHPidana dan KUHAP yang mengatur tentang pidana dan hukum acara pidana, serta putusan hakim khususnya dalam perkara pidana Narkotika yang disebutkan di atas.

Jenis pendekatan yang digunaan dalam penelitian ini yaitu pertama pendekatan perundang-undangan yang diteliti adalah berbagai aturan hukum yang menjadi fokus sekaligus tema sentral suatu penelitian, kedua pendekatan kasus memiliki tujuan untuk memahami koneksivitas kasus hukum dalam kehidupan masyarakat terutama apabila terkait dengan yurisprudensi, ketiga pendekatan analitis mengetahui makna yang dikandung oleh istilah-istilah yang digunakan dalam aturan perundang-undangan secara konsepsional sekaligus mengetahui penerapannya dalam praktik dan putusan-putusan hukum.

\section{PEMBAHASAN}

Analisis Putusan Pengadilan Negeri Surabaya Nomor: 3094/Pid.B/2013 Sesuai dengan Alat Bukti yang diajukan di Persidangan.

Gambaran perkara Hengki Steven (No. 3094/Pid.B/2013)

\section{Posisi Kasus:}

Hengki Steven, terdakwa kasus kepemilikan sabu seberat 472 gram akhirnya dihukum 10 tahun penjara oleh majelis hakim yang diketuai Sri Herawati, Selasa (24/6/2014).Terdakwa yang juga berstatus sebagai narapidana lapas Pamekasan ini divonis lebih berat dari tuntutan jaksa penuntut umum (JPU) Deddy Agus Oktavianto, dari Kejari Surabaya yang dibacakan pada sidang sebelumnya. JPU menuntut terdakwa dengan hukuman 7 tahun kurungan penjara denda Rp 1 milyar subsider 3 bulan penjara.Kasus ini berawal pada Agustus 2013 lalu. Sigit Saputra dan Lia Wulandari diperintah oleh terdakwa menerima paket berisi sabu dan membagikan sabu dalam paket kecil-kecil. 
Namun saat paket ditangan mereka, petugas BNN langsung datang menyergap. Keduanya tidak berkutik, lantaran saat paket dibuka, dipastikan berisi narkotika jenis shabu-shabu dengan berat kotor 472,2 gram. Oleh terdakwa, melalui HP, kedua kurirnya tersebut dimintanya untuk membagi sabu-sabu yang sudah diterima dalam poket-poket kecil. Dari terdakwa, petugas lantas mendapati nama Celin yang diketahui sebagai pemasok sabu-sabu pada terdakwa.

Putusan hakim merupakan mahkota dan puncak dari suatu perkara yang sedang diperiksa dan diadili oleh hakim tersebut. Oleh karena itu, hakim dalam membuat putusan harus memperhatikan segala aspek di dalamnya, mulai dari perlunya kehati-hatian, dihindari sedikit mungkin ketidakcermatan, baik yang bersifat formal maupun materiil sampai dengan adanya kecakapan teknik membuatnya. Jika hal-hal negatif tersebut dapat dihindari, tentu saja diharapkan dalam diri hakim hendaknya lahir, tumbuh, dan berkembang adanya sikap atau sifat kepuasaan moral jika kemudian putusan yang dibuatnya dapat menjadi tolak ukur untuk perkara yang sama, atau dapat menjadi bahan referensi bagi kalangan teoretisi maupun praktisi hukum serta kepuasan nurani tersendiri jika putusannya dikuatkan dan tidak dibatalkan pengadilan yang lebih tinggi (Lilik Mulyadi, 2007,25).

Jika seorang hakim menjatuhkan suatu putusan, maka ia akan selalu berusaha agar putusannya nanti seberapa mungkin dapat diterima masyarakat, setidak-tidaknya berusaha agar lingkungan orang yang akan dapat menerima putusannya seluas mungkin. Hakim merasa lebih lega manakala putusannya dapat memberikan kepuasan pada semua pihak dalam suatu perkara, dengan memberikan alasan-alasan atau pertimbangan-pertimbangan yang sesuai dengan nilai-nilai kebenaran dan keadilan.

Proses penjatuhan putusan yang dilakukan hakim merupakan proses yang kompleks dan sulit, sehingga memerlukan pelatihan, pengalaman, dan kebijaksanaan. Dalam proses penjatuhan putusan tersebut, seorang hakim harus meyakini apakah seoarang terdakwa melakukan tindak pidana atau tidak, dengan tetap berpedoman pada pembuktian untuk menentukan kesalahan dari perbuatan yang dilakukan oleh seorang pelaku pidana (Ahmad Rifai, 2011, 95).

Setelah menerima dan memeriksa suatu perkara, selanjutnya hakim akan menjatuhkan keputusan, yang dinamakan dengan putusan hakim, yang 
merupakan pernyataan hakim sebagai pejabat negara yang diberi wewenang untuk itu, yang diucapkan dalam sidang pengadilan yang terbuka untuk umum, yang bertujuan untuk mengakhiri atau menyelesaikan suatu perkara.

Adapun putusan hakim dalam perkara pidana, dapat berupa putusan penjatuhan pidana, jika perbuatan pelaku tindak pidana terbukti secara sah dan meyakinkan, putusan pembebasan dari tindak pidana (vrijspraak), dalam hal menurut hasil pemeriksaan di persidangan, kesalahan terdakwa tidak terbukti secara sah dan meyakinkan atau berupa putusan lepas dari segala tuntutan hukum (onslaag van alle rechtsvervolging), dalam hal perbuatan terdakwa sebagaimana yang didakwakan terbukti, akan tetapi perbuatan tersebut tidak merupakan suatu tindak pidana (Pasal 191 ayat (1) KUHAP).

Proses atau tahapan penjatuhan putusan oleh hakim, dalam perkara pidana, menurut Yusti Probowati Rahayu (2005, 85):

\section{Tahap Menganalisis Perbuatan Pidana}

Perbuatan pidana dapat diberi arti perbuatan yang dilarang dan diancam pidana, barang siapa melanggar larangan tersebut. Moelyatno membedakan pula antara perbuatan pidana dengan tanggung jawab pidana.

Pada saat hakim menganalisis, apakah terdakwa melakukan perbuatan pidana atau tidak, yang dipandang primer adalah segi masyarakat, yaitu perbuatan sebagai tersebut dalam rumusan suatu aturan pidana. Ditinjau dari segi tersebut tampak sebagai perbuatan yang merugikan atau yang tidak patut dilakukan atau tidak. Jika perbuatan terdakwa memenuhi unsur-unsur dalam suatu pasal hukum pidana, maka terdakwa dinyatakan terbukti melakukan perbuatan pidana yang didakwakan kepadanya. Unsur dalam perbuatan pidana sebagaimana terdapat dalam KUHPidana, dibedakan menjadi unsur umum dan unsur batasan pengertian (Moelyatno, 1982; Yusti Probowati, 2005, 85).

\section{Tahap Menganalisis Tanggung Jawab Pidana}

Jika seorang terdakwa dinyatakan terbukti melakukan perbuatan pidana melanggar suatu pasal tertentu, hakim menganalisis apakah terdakwa dapat dinyatakan bertanggung jawab atas perbuatan pidana yang dilakukannya. Pada saat menyelidiki apakah terdakwa yang melakukan perbuatan pidana dapat dipertanggungjawabkan perbuatannya, yang dipandang primer adalah orang itu sendiri. 
Dapat dipidananya seseorang harus memenuhi dua syarat, yaitu pertama, perbuatan yang bersifat melawan hukum sebagai sendi perbuatan pidana, dan yang kedua, perbuatan yang dilakukan itu dapat dipertanggungjawabkan sebagai suatu kesalahan (asas geen straf zonder schuld).

Unsur-unsur pertanggungjawaban pidana untuk membuktikan adanya kesalahan pidana yang dilakukan oleh terdakwa harus dipenuhi hal-hal sebagai berikut:

a. Melakukan perbuatan pidana (sifat melawan hukum).

b. Di atas umur tertentu dan mampu bertanggung jawab.

c. Mempunyai suatu bentuk kesalahan yang berupa kesengajaan atau kealpaan.

d. Tidak adanya alasan pemaaf.(Moelyatno, 1982, 60)

Menurut Ahmad Rifai, hakim dapat menggunakan Pasal 44 s.d. 50 KUH Pidana tentang orang-orang yang dinyatakan tidak dapat bertanggungjawab atas perbuatan pidana yang dilakukannya tersebut, yaitu sebagai berikut:

1. Dalam diri orang itu (inwendig), yaitu yang disebut sebagai alasan pemaaf, yaitu menghapus kesalahan terdakwa menyangkut diri pribadi si terdakwa, sehingga terdakwa tidak dapat dicela dan oleh karenanya menghapus kesalahan terdakwa, yang terdiri atas:

a. Pasal 44 ayat (1) KUH Pidana, ada 2 hal yang menyebabkan seseorang yang melakukan tindak pidana tidak dapat dikenakan pertanggungjawaban, sehingga si pelaku tidak dapat dipidana, yaitu:

Pertama, orang yang pertumbuhan akalnya tidak sempurna atau kurang sempurna misalnya: orang idiot, lemah akal, dan lain-lain.

Kedua, orang yang mengalami gangguan penyakit pada kemampuan akal sehatnya, misalnya sakit ingatan/gila, klpetomania, piromania, nimfomania.

b. Pasal 45 KUH Pidana mengenai batas usia anak yang belum dewasa yang tidak dapat dipidana menurut pasal 45 KUH Pidana adalah sampai dengan batas usian 16 tahun, dimana hakim boleh memerintahkan agar si pelaku dikembalikan kepada orang tua, wali, atau pengampunya, dengan tidak mengenakan suatu hukuman atau memerintahkan diserahkan kepada pemerintah (UU No. 3 tahun 1997). 
c. Pasal 49 ayat (2) KUH Pidana: melampui pembelaan terpaksa (noodweer exess), dengan syarat-syarat, yang pertama, kelampauan batas pembelaan yang diperlukan, yang kedua, kelampauan dilakukan sebagai akibat yang langsung dari kegoncangan jiwa yang hebat (suatu paksaan hati yang sangat panas), dan yang ketiga, kegoncangan jiwa yang hebat itu disebabkan adanya serangan, dengan kata lain antara kegoncangan jiwa tersebut dan serangan harus ada hubungan sebab akibat/kausalitas.

d. Pasal 51 ayat (2) KUH Pidana, yaitu melaksanakan perintah jabatan dari pembesar yang tidak berhak tetapi dilakukan dengan itikad baik oleh orang yang disuruh tersebut.

2. Di luar diri orang itu (uitwendig), yaitu yang disebut sebagai alasan pembenar, yaitu menghapuskan sifat melawan hokum perbuatan, meskipun perbuatan memenuhi rumusan delik dalam Undang-Undang, akan tetapi perbuatan tersebut dibenarkan , terdiri atas:

a. Pasal 48 KUH Pidana: melakukan tindak pidana karena daya paksa/overmacht, yaitu:

Pertama, Vis absoluta (paksaan yang absolut) atau overmacht yang bersifat luas, yang disebabkan oleh manusia atau alam (paksaan tersebut sama sekali tidak dapat ditahan);

Kedua, Vis compulsiva (paksaan yang relatif/psikologis) atau overmacht yang bersifat sempit, yaitu suatu keadaan darurat, dimana terjadi perbenturan antara dua kepentingan hokum, perbenturan antara kepentingan hokum dan kewajiban hukum dan perbenturan antara dua kewajiban hukum.

b. Pasal 49 ayat (1) KUH Pidana: untuk membela dirinya, diri orang lain, kesopanan, harta benda dari serangan melawan hukum dan seketika itu (pembelaan terpaksa/noodweer), dengan terlebih dahulu memenuhi 2 (dua) syarat, yaitu pertama, ada serangan yang seketika langsung mengancam, melawan hukum, dan sengaja ditujukan pada badan, nyawa, kesusilaan, dan harta, yang kedua, ada pembelaan yang perlu diadakan, yang menyangkut badan, nyawa, kesusilaan, dan harta.

c. Pasal 50 KUH Pidana: melaksanakan perbuatan karena menjalankan peraturan undang-undang (melaksanakan undang-undang). 
d. Pasal 51 ayat (1) KUH Pidana: melaksanakan perintah jabatan.

Namun demikian, dalam hal analisis hakim terhadap pelaku tindak pidana narkotika, ternyata sehat lahir dan batinnya serta tidak adanya alasan pemaaf maupun alasan pembenar yang dapat menghapuskan sifat melawan hukum dari perbuatan pidana yang dilakukan oleh terdakwa (pelaku), maka hakim menyatakan pelaku sebagai orang yang dapat mempertanggungjawabkan di hadapan hukum.

\section{Tahap Penentuan Pidana}

Dalam hal ini, jika hakim berkeyakinan bahwa pelaku telah melakukan perbuatan yang melawan hukum, sehingga ia dinyatakan bersalah atas perbuatannya, dan kemudian perbuatannya itu dapat dipertanggungjawabkan oleh si pelaku, maka hakim akan menjatuhkan pidana terhadap pelaku tersebut, dengan melihat pasal-pasal undang-undang yang dilangggar oleh si pelaku. Besarnya pemidanaan yang dijatuhkan oleh hakim telah diatur dalam KUH Pidana, dimana KUH Pidana telah mengatur pemidanaan maksimal yang dapat dijatuhkan hakim dalam perbuatan pidana tertentu. Hal ini untuk menjaga kebebasan hakim dalam memutuskan suatu perkara berdasarkan kasusnya.

Dalam menjatuhkan pidana terhadap para pelaku tindak pidana narkotika, maka hakim dapat menggunakan beberapa teori penjatuhan pidana seperti halnya teori keseimbangan, teori pendekatan seni dan instuisi, teori pendekatan keilmuan, teori pendekatan pengalaman, teori ratio decidendi dan teori kebijaksanaan.

\section{Parameter Pembuktian yang Dinilai Hakim dalam Tindak Pidana Pasal 114 ayat (2) juncto Pasal 132 ayat (1) UU RI Nomor 35 Tahun 2009 tentang Narkotika}

Ada empat hal terkait konsep pembuktian itu sendiri: pertama, suatu bukti haruslah relavan dengan sengketa atau perkara yang sedang diproses. Artinya, bukti tersebut berkaitan dengan fakta-fakta yang menunjuk pada suatu kebenaran suatu peristiwa.

Kedua, suatu bukti harus dapat diterima atau admissible. Biasanya suatu bukti yang diterima dengan sendirinya relavan (Arthur Best, 1994, 1). Sebaliknya, suatu bukti yang tidak relavan, tidak akan dapat diterima. Kendatipun demikian, dapat saja suatu bukti relavan, tetapi tidak dapat diterima. Misalnya adalah 
testimoni de auditu atau hearsay, yakni mendengar kesaksian dari orang lain. Tegasnya, suatu bukti yang dapat diterima pasti relavan, namun tidak sebaliknya, suatu bukti yang relavan belum tentu dapat diterima. Dengan kata lain, primafacie dari bukti yang diterima adalah bukti yang relavan.

Dalam encyclopedia of crime \& Justice, admissible evidence didefinisikan sebagai lisan, tulisan, fotografi, atau bukti materiil lainnya yang dipertimbangkan oleh hakim untuk dapat diterima berdasarkan hukum pembuktian (Joshua Dressler, 2002, 196). Artinya, dapat atau tidak diterimanya suatu bukti didasari atas pertimbangan hakim.

Ketiga, hal yang disebut sebagai exclusionary rules. Dalam literatur dikenal dengan istilah exclusionary discretion. Phyllis B.Gerstenfeld (2008, 348), memberi definisi exclusionary rules sebagai prinsip hukum yang mensyaratkan tidak diakuinya bukti yang diperoleh secara melawan hukum. Tegasnya, peraturan yang mensyaratkan bukti yang diperoleh secara illegal tidak dapat diterima di pengadilan (Mark Constanzo, 2006, 500). Terlebih dalam konteks hukum pidana, kendatipun suatu bukti relevan dan dapat diterima dari sudut pandang penuntut umum, bukti tersebut dapat dikesampingkan oleh hakim bilamana perolehan bukti tersebut dilakukan tidak sesuai dengan aturan.

Exclusionary rules membolehkan seorang terdakwa mencegah penuntut umum mengajukan bukti di pengadilan sebagai bukti yang dapat diterima karena diperoleh secara inkonstitusional. Exclusionary rule juga dapat menolak bukti probatif dengan konsekuensi meniadakan tuntutan jaksa. Namun, biasanya setiap sistem hukum mengesampingkan bukti yang telah dipertimbangkan jika bukti tersebut tidak relevan atau tidak dapat dipercaya (Joshua Dressler, 2002, 196).

Keempat, dalam konteks pengadilan, setiap bukti yang relavan dan dapat diterima harus dapat dievaluasi oleh hakim. Dalam konteks yang demikian, kita memasuki kekuatan pembuktian atau bewijskracht. Maka, hakim akan menilai setiap alat bukti yang diajukan ke pengadilan, kesesuain antara bukti yang satu dengan bukti yang lain, kemudian akan menjadikan bukti-bukti tersebut sebagai dasar pertimbangan hakim dalam mengambil putusan.

Hukum pembuktian meliputi hal yang sangat luas. Di sini hukum pembuktian meliputi segala sesuatu yang berkaitan dengan pembuktian itu sendiri, dimulai dari tahap pengumpulan bukti, penyampaian bukti sampai ke 
pengadilan, penilaian terhadap setiap bukti sampai pada beban pembuktian di pengadilan.

Perkembangan hukum pembuktian sangat berpengaruh bagi perkara yang sedang ditangani dan bukti yang dimiliki. Perkembangan zaman, termasuk perkembangan teknologi dan ilmu pengetahuan, akan sangat berpengaruh pada hukum pembuktian.

Hukum pembuktian bukanlah sistem yang teratur. Kuat atau lemahnya pembuktian tergantung pada kesesuaian antara fakta yang satu dengan fakta yang lain yang dapat dibuktikan dan diyakinkan kepada hakim. Ada kalanya material fact atau fakta-fakta pokok yang harus dibuktikan pada kenyataannya tidak bisa meyakinkan hakim. Maka, dengan sendirinya pembuktian atas fakta tersebut dianggap lemah. Dapat juga fakta yang satu yang harus membuktikan fakta yang lain (factum probandum) terdapat ketidaksesuaian sehingga pembuktian yang demikian juga dianggap lemah.

Tidak ada satu kesatuan hukum pembuktian yang dapat diterapkan untuk semua proses hukum. Dalam konteks hukum pembuktian di Indonesia, masingmasing lapangan hukum memiliki hukum pembuktian sendiri. Tindak pidana umum yang ada dalam KUHP Pidana, pembuktiannya mengikuti apa yang terdapat dalam Kitab Undang-Undang Hukum Acara Pidana (KUHAP), sedangkan tindak pidana khusus, masing-masing memiliki hukum pembuktian tersendiri salah satunya tindak pidana narkotika.

\section{PENUTUP}

\section{Kesimpulan}

Putusan hakim terasa begitu dihargai dan mempunyai nilai kewibawaan, jika putusan tersebut dapat merefleksikan rasa keadilan bagi masyarakat dan juga merupakan sarana bagi masyarakat pencari keadilan untuk mendapatkan kebenaran dan keadilan. Sebelum seorang hakim memutus suatu perkara, maka ia akan menanyakan kepada hati nuraninya sendiri, apakah putusan ini nantinya akan adil dan bermanfaat (kemashlahatan) bagi manusia ataukah sebaliknya, akan lebih banyak membawa kepada kemudharatan bangsa dan negaranya, sehingga untuk itulah diharapkan seorang hakim harus peka dengan problematika yang semakin menghancurkan kualitas hidup anak bangsa, dalam hal ini peredaran 
narkotika yang semakin merajalela. Maka sangat diharapkan hakim harus bekerja secara professional, bersih, dan bijaksana, serta mempunyai rasa kemanusiaan yang tinggi terhadap bangsa dan negaranya.

Kuat atau lemahnya pembuktian tergantung pada kesesuaian antara fakta yang satu dengan fakta yang lain yang dapat dibuktikan dan diyakinkan kepada hakim. Ada kalanya material fact atau fakta-fakta pokok yang harus dibuktikan pada kenyataannya tidak bisa meyakinkan hakim. Maka, dengan sendirinya pembuktian atas fakta tersebut dianggap lemah. Dapat juga fakta yang satu yang harus membuktikan fakta yang lain (factum probandum) terdapat ketidaksesuaian sehingga pembuktian yang demikian dianggap lemah.

\section{Saran}

Putusan hakim harus memihak dan peka pada nasib dan keadaan bangsa dan negaranya. Seiring dengan kian hari semakin meningkatnya tindak pidana terhadap Undang-Undang Nomor 35 Tahun 2009 tentang Narkotika. Sehingga, bertujuan untuk meningkatkan kesejahteraan dan kemaslahatan masyarakat serta membawa bangsa dan negara keluar dari keterpurukan di segala bidang kehidupan.

Dengan adanya lembaga Badan Narkotika Nasional (BNN), diharapkan para pihak penegak hukum harus bersinergi dalam upaya pemberantasan narkoba dengan lembaga terkait. Pertimbangan penjatuhan putusan oleh hakim harus menyesuaikan dengan karakter hukum dan parameter pembuktian alat bukti yang diajukan di persidangan, sehingga tidak ada pembiaran atau pembebasan pelaku tindak pidana narkotika. Dan tidak menimbulkan multitafsir undang-undang yang ada oleh para penegak hukum, dan hakim harus benar-benar menjatuhkan putusan sesuai dengan rasa keadilan dan kemanfaatan hukum selaras dengan Undang-Undang RI Nomor 35 Tahun 2009 Tentang Narkotika.

\section{DAFTAR PUSTAKA}

\section{Buku Literatur}

Ahmad Rifai., 2011, Penemuan Hukum Oleh Hakim dalam Perspektif Hukum Progresif, Sinar Grafika, Jakarta.

Best, Arthur., 1994, Evidence: Examples and Explanations, Brown and Company, Bostnon-New York-Toronto-London.

Constanzo, Mark., 2006, Aplikasi Psikologis dalam Sistem Hukum, Pustaka Pelajar, Yogyakarta. 
Dressler, Joshua (Edt)., 2002, Encyclopedia of Crime \& Justice, 2nd Edition, Volume 4: Wiretapping \& Eavesdropping, Gale Group Thomson Learning.

Gerstenfeld, Phyllis B., 2008, Crime \& Punishment In The United States, Salem Press, California.

Koesno Adi., 2009, Kebijakan Kriminal dalam Penanggulangan Tindak Pidana Narkotika oleh Anak, UMM Press, Malang.

Lili Rasjidi \& Ira Thania Rasjidi., 2004, Dasar-Dasar Filsafat dan Teori Hukum, Citra Aditya Bakti, Bandung.

Mulyadi, Lilik., 2007, Pembalikan Beban Pembuktian Tindak Pidana Korupsi, Alumni, Bandung.

Moelyatno., 1982, Asas-Asas Hukum Pidana, Universitas Gajah Mada, Yogyakarta.

Rahayu, Yusti Probowati., 2005, Dibalik Putusan Hakim, Kajian Psikologi Hukum dan Perkara Pidana, Citramedia, Sidoarjo.

Waluyo, Bambang., 2004. Pidana dan Pemidanaan. Sinar Grafika, Jakarta.

\section{Peraturan Perundang-Undangan:}

KUH Pidana

KUHAP

Undang-Undang Nomor 3 Tahun 1997.

Undang-Undang Nomor 35 Tahun 2009.

\section{Majalah:}

Lilik Mulyadi., 2006, sebagaimana terdapat dalam Makalah H. Muchsin. Peranan Putusan Hakim pada Kekerasan dalam Rumah Tangga, Majalah Hukum Varia Peradilan Edisi No. 260 Bulan Juli, Ikahi, Jakarta.

., 2006, Pergeseran Perspektif dan Praktik dari Mahkamah Agung Mengenai Putusan Pemidanaan, Majalah Hukum Varia Peradilan Edisi No. 246 Bulan Mei, Ikahi, Jakarta.

Tabloid Hukum terdepan di Jatim., 2013, Indonesia news, (edisi: 232/ 20$30 / 10)$. 